\title{
Identification of Tn2401, a Transposon Encoding Multiresistance to Aminoglycosides
}

\author{
By FRIEDRICH SCHMIDT, * JOHANNES KRATZ AND \\ BERND WIEDEMANN \\ Institut für Medizinische Mikrobiologie und Immunologie der Universität Bonn, \\ An der Immenburg 4, 5300 Bonn 1, Federal Republic of Germany
}

(Received 19 August 1982; revised 15 November 1982)

\begin{abstract}
A transposable element, Tn2401, was found in a clinical isolate of Pseudomonas aeruginosa. Tn2401 had a size of 7190 nucleotides and encoded aminoglycoside $3^{\prime}$-phosphotransferase and aminoglycoside 6 '- $N$-acetyltransferase. The sequence encoding the former enzyme was homologous with that of Tn903. Pseudomonas aeruginosa strains harbouring this transposon were resistant to kanamycin, neomycin, lividomycin, ribostamycin, paromomycin, netilmycin, tobramycin, dibekacin, gentamicin, sisomicin, and butirosin.
\end{abstract}

\section{INTRODUCTION}

Aminoglycoside antibiotics such as gentamicin, tobramycin, sisomicin, dibekacin, and amikacin are still of great importance in the treatment of life-threatening infections, but there are many reports of serious infections caused by aminoglycoside-resistant Enterobacteriaceae and Pseudomonas strains in hospitals (Acar et al., 1977; Yoshikawa et al., 1978). In clinical isolates resistance to aminoglycoside-aminocyclitol antibiotics is usually associated with the presence of enzymes that catalyse $\mathrm{N}$-acetylation, $\mathrm{O}$-phosphorylation, or $\mathrm{O}$-adenylylation of amino or hydroxyl groups on the drug molecule (Beneviste \& Davies, 1973). Some of these aminoglycoside modifying enzymes are encoded by genes capable of moving from one replicon to another in the absence of host-mediated recombination functions. Such movable genetic elements have been termed transposons (Starlinger, 1980). Two of them, Tn903 and Tn5, encode aminoglycoside $3^{\prime}$-phosphotransferases APH-(3')I and APH-(3')II, respectively, which phosphorylate kanamycin, neomycin, and related compounds (Yamamoto \& Yokota, 1980). Nugent et al. (1979) identified $\operatorname{Tn} 732$, the first transposon mediating multiple resistance to the more 'modern' aminoglycosides such as gentamicin, tobramycin, sisomicin, and dibekacin by the production of aminoglycoside 2 "-adenylyltransferase [ANT-(2")].

In this paper we report the identification of a transposon coding for the production of two inactivating enzymes: the aminoglycoside $3^{\prime}$-phosphotransferase, APH-( $\left.3^{\prime}\right) \mathrm{I}$, which mediates resistance to kanamycin, neomycin, paromomycin, ribostamycin, and lividomycin; and the aminoglycoside $6^{\prime}-N$-acetyltransferase, AAC- $\left(6^{\prime}\right)$, which modifies gentamicin, tobramycin, sisomicin, kanamycin, neomycin, dibekacin, butirosin, and netilmycin.

\footnotetext{
Abbreviations: AAC- $\left(6^{\prime}\right)$, aminoglycoside $6^{\prime}-N$-acetyltransferase (EC 2.3.1.55); ANT-(2"), aminoglycoside $2^{\prime \prime}-$ adenylyltransferase (EC 2.7.7.46); APH-(3')I, aminoglycoside 3'-phosphotransferase (EC 2.7.1.95); APH-(6), aminoglycoside 6-phosphotransferase (EC 2.7.1.72); Ap, ampicillin; But, butirosin; Cm, chloramphenicol; Dk, dibekacin; Gm, gentamicin; Km, kanamycin; Liv, lividomycin; Nal, nalidixic acid; Net, netilmycin; Nm, neomycin: Pm, paromomycin; Rif, rifampicin; Rm, ribostamycin; Sis, sisomicin; Sm, streptomycin; Su, sulphonamides; Tc, tetracycline; Tm, tobramycin.
} 


\section{METHODS}

Bacterial strains and plasmids. These are listed in Table 1.

Culture conditions. Growth media and testing of antibiotic sensitivity were as described recently (van Treeck et al., 1981).

Plasmid techniques. Preparation of plasmid DNA, restriction enzyme analysis, conjugational transfer and transformation of DNA were carried out as described previously (Schmidt et al., 1982).

Measurement of enzyme activities. Substrate activities of aminoglycoside modifying enzymes were measured according to the paper binding method (Beneviste \& Davies, 1971).

Transposition experiments and phage techniques. Transposition of aminoglycoside resistance markers to $\mathrm{PlCmCl}$, preparation of phage lysates by heat induction, phage titration, tests for phage production, plaque centre tests, determination of phage immunity and transduction were done as described by Iida \& Arber (1977). Curing of phage lysogenic cells was done as described by Rosner (1972), with the addition of 5 mm-citrate to prevent phage reinfection.

Heteroduplex analysis. This was performed according to the formamide technique of Davis et al. (1971). For length calculations, double and single stranded DNA of phage $\phi$ X174 was used as an internal standard, giving a length of $5375 \mathrm{bp}$ (Sanger et al., 1977). The contour length of DNA was measured with a Numonics digitizer.

Hybridization of DNA separated on agarose gels. The method of Southern (1975) as adapted to DNA-DNA hybridization by Botchan et al. (1976) was used with minor modifications (Wahl et al., 1979). P1Cm ts $_{\text {DNA was }}$ nick-translated as described by Maniatis et al. (1975).

\section{RESULTS}

Transposition of aminoglycoside genes on to various phages and plasmids

Plasmid pBP30, coding for the production of APH-(3')I, APH-(6), and AAC-(6'), was originally found in Pseudomonas aeruginosa 141, which was isolated from a clinical specimen at the University Hospital, Bonn. pBP30 is a nonconjugative plasmid of $43.2 \mathrm{~kb}$ and confers resistance only to aminoglycoside antibiotics (Table 1). Resistance to aminoglycosides mediated by the AAC- $\left(6^{\prime}\right)$ enzyme (gentamicin, tobramycin, dibekacin, sisomicin, netilmycin and butirosin, see Table 1) is only weakly expressed in Escherichia coli hosts, as could be demonstrated by transfer of pBP30 DNA according to the method of Sinclair \& Morgan (1978). Plasmid pBP30 DNA was isolated from $P$. aeruginosa 141 , transformed to $E$. coli and back to $P$. aeruginosa (Wiedemann \& Weppelmann, 1981). Escherichia coli transformants produced all three transferases, but were resistant only to kanamycin, neomycin, paromomycin, lividomycin, streptomycin, tobramycin, and dibekacin.

By the use of the method of Iida \& Arber (1977), a potential transposon was identified from pBP30 with the aid of bacteriophage P1Cm ${ }_{\mathrm{ts}}$. Plasmid DNA from E. coli strain SK 1592(pBP30) was transformed into $E$. coli $\mathrm{C} 600 \mathrm{Sm}^{\mathrm{r}} \mathrm{rec} A$ that was lysogenic for phage $\mathrm{P} 1 \mathrm{Cm}_{\mathrm{ts}}$. Phage lysates were prepared by heat induction (Iida \& Arber, 1977) and used to infect $E$. coli WA921. Kanamycin-resistant clones were selected at $30^{\circ} \mathrm{C}$, and checked for resistance to tobramycin. A total of 15 strains were selected and phages were checked by plaque centre testing (Iida \& Arber, 1977) for resistance to chloramphenicol, kanamycin, and tobramycin. Two $\mathrm{P} 1 \mathrm{Cm}_{\mathrm{ts}} \mathrm{Km}^{\mathrm{r}} \mathrm{Tm}^{\mathrm{r}}$ lysogenic strains were isolated, induced to prepare phage lysates, and 49 single plaques were again tested by the plaque centre test. Of 49 plaques, 43 contained $P 1 \mathrm{Cm}_{\mathrm{ts}} \mathrm{Km}^{\mathrm{r}} \mathrm{Tm}^{\mathrm{r}}$ phages. The resistance patterns of the clones lysogenic for transposon-bearing phages demonstrated that the sequence transposed to $\mathrm{P} 1 \mathrm{Cm}_{\mathrm{ts}}$ carried the genes for two of the aminoglycoside modifying enzymes, APH-( $\left.3^{\prime}\right) \mathrm{I}$ and AAC- $\left(6^{\prime}\right)$. In agreement with the Plasmid Reference Center this transposon has been designated Tn2401 (Lederberg, 1981).

In order to determine the physical characteristics of the transposable element, E. coli JC2926 rec $A$ carrying pBR322 was infected with $\mathrm{P} 1 \mathrm{Cm}_{\mathrm{ts}} \mathrm{Km}^{\mathrm{r}} \mathrm{Tm}^{\mathrm{r}}$ phages at a multiplicity of 1 p.f.u. per cell. Lysogens were selected on ampicillin plus kanamycin medium at $30^{\circ} \mathrm{C}$ and tested for resistance to ampicillin, tetracycline, chloramphenicol, kanamycin and tobramycin, and for phage production. Six strains were isolated and cured for bacteriophage production by incubation of diluted overnight cultures on ampicillin plus kanamycin medium at $42^{\circ} \mathrm{C}$ (Rosner, 1972). After incubation for $24 \mathrm{~h}$ at $42^{\circ} \mathrm{C}$, survivors were further purified on ampicillin plus kanamycin medium at $42^{\circ} \mathrm{C}$ and tested for chloramphenicol sensitivity, phage sensitivity, 
Table 1. Bacterial strains, plasmids and phages

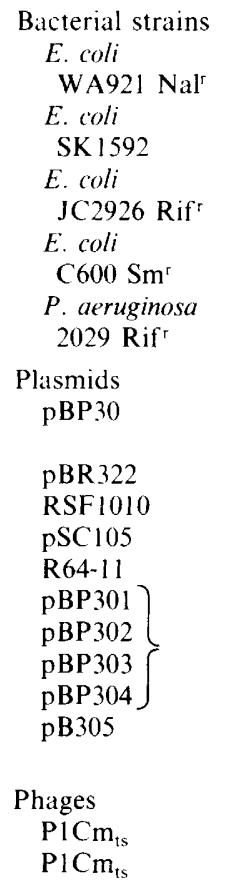

Relevant characteristics

lac thr leu met thi hsd

gal thi $\mathrm{Tl}^{\mathrm{r}}$ sbcB15 hsdR4 hsdM endA

recA thi thr arg his leu mal

recA thr leu thi tonA

leu res

$\mathrm{Sm}^{r} \mathrm{Km}^{r} \mathrm{Nm}^{r} \mathrm{Pm}^{r} \mathrm{Liv}^{r} \mathrm{Rm}^{r} \mathrm{Tm}^{r} \mathrm{Dk}^{r} \mathrm{Gm}^{r}$

Net $^{r}$ Sis $^{r}$ But $^{\top}$

$\mathrm{Ap}^{\mathrm{r}} \mathrm{Tc}^{\mathrm{r}}$

$\mathrm{Sm}^{r} \mathrm{Su}^{\mathrm{r}}$

$\mathrm{Km}^{\mathrm{r}} \mathrm{Tc}^{\mathrm{r}}$

Mutant of R64: $\mathrm{Te}^{r} \mathrm{Km}^{r}$

$\mathrm{Ap}^{\mathrm{r}}$

aphA $\left(\mathrm{Km}^{\mathrm{r}} \mathrm{Nm}^{\mathrm{r}} \mathrm{Pm}^{\mathrm{r}} \mathrm{Liv}^{\mathrm{r}} \mathrm{Rm}^{\mathrm{r}}\right)$

aacA $\left(\mathrm{Tm}^{\mathrm{r}} \mathrm{Dk}^{r} \mathrm{Gm}^{r} \mathrm{Net}^{r} \mathrm{Sis}^{r} \mathrm{But}^{r}\right)$

$\mathrm{Sm}^{r} \mathrm{Km}^{\mathrm{r}} \mathrm{Nm}^{\mathrm{r}} \mathrm{Pm}^{\mathrm{r}} \mathrm{Liv}^{\mathrm{r}} \mathrm{Rm}^{\mathrm{r}} \mathrm{Tm}^{\mathrm{r}} \mathrm{Dk}^{\mathrm{r}} \mathrm{Gm}^{\mathrm{r}}$ Net $^{r}$ Sis $^{r}$ But ${ }^{r}$

Heat inducible: $\mathrm{Cm}^{\mathrm{r}}$

Heat inducible: $\mathrm{Cm}^{r} \mathrm{Km}^{r} \mathrm{Nm}^{\mathrm{r}} \mathrm{Pm}^{r} \mathrm{Liv}^{r} \mathrm{Rm}^{\mathrm{r}}$

$\mathrm{Tm}^{r} \mathrm{Dk}^{r} \mathrm{Gm}^{r}$ Net $^{r}$ Sis But ${ }^{r}$
Source or reference

Wood (1966)

Kushner (1978)

Bachmann (1972)

Cohen et al. (1972)

A. M. Chakrabarty

Wiedemann \& Weppelmann (1981)

Bolivar et al. (1977)

Guerry et al. (1974)

Nisen et al. (1977)

Meynell \& Datta (1976)

This paper; pBR322::Tn2401

This paper; Pst I fragment $\mathrm{C}$ of pBP301 inserted in RSF1010

Mise et al. (1976)

This paper

bacteriophage production and resistance to ampicillin, tetracycline, kanamycin, and tobramycin (Rosner, 1972).

Four clones which produced no bacteriophages (i.e. cured cells) were picked and further characterized. They exhibited resistance to ampicillin, kanamycin, and tobramycin but were sensitive to tetracycline.

Cell-free extracts of the four strains carrying pBR $322:: \operatorname{Tn} 2401$ were tested for the presence of aminoglycoside modifying enzymes. Besides the MIC values, the results of these assays (Table 2) clearly showed that the chimaeric plasmids produced APH-(3')I and AAC- $\left(6^{\prime}\right)$. Resistance to streptomycin or inactivation of that drug did not occur. However, when bacteria bearing pBR322::Tn2401 were subjected to osmotic shock (Beneviste \& Davies, 1971), the cell-free supernatants had definite but lower levels of AAC- $\left(6^{\prime}\right)$ than those of $P$. aeruginosa 141 . When the DNA segment of pBP301 (pBR322::Tn2401), containing the AAC- $\left(6^{\prime}\right)$ gene (aacA; PstI fragment $\mathrm{C}$, see also below) was cloned into RSF1010, and the resulting chimaeric plasmid, pBP305, was transferred to $P$. aeruginosa 2029 , these cells contained $100 \%$ more AAC- $\left(6^{\prime}\right)$ than similar preparations from SK 1592 harbouring pBP301. The observation that aacA is only weakly expressed in $E$. coli strains cannot be explained from our experimental approach.

From agarose gel electrophoresis, hybrid plasmids pBR322: :Tn2401, prepared from all four clones had a size of $11.5 \mathrm{~kb}$, indicating the transposition of a $7 \cdot 1 \mathrm{~kb}$ DNA sequence on to pBR322. The purified DNAs of these plasmids, pBP301, pBP302, pBP303, and pBP304, were compared by digestion with restriction endonuclease $B g l$. They all yielded 12 fragments (Table 3 ), forming identical restriction patterns in agarose slab gels, indicating that the aminoglycoside resistance genes had transposed to the same site in $\mathrm{pBR} 322$, i.e. the $\mathrm{Tc}^{\mathrm{r}}$ gene, corresponding with the loss of tetracycline resistance.

To exclude the possibility that sequences from pBP30 had been picked by a $\operatorname{rec} A$-independent process directed by the ISl elements or other sequences in $\mathrm{P} 1 \mathrm{Cm}_{\mathrm{ts}}$, DNA sequence homology between phage DNA and restriction fragments of the hybrid plasmids was tested by Southern 
Table 2. Acetylation, phosphorylation and MIC values of aminoglycosides by Tn2401-encoded transferases $A A C-\left(6^{\prime}\right)$ and $A P H-\left(3^{\prime}\right) I$

\begin{abstract}
Abbreviations: A, acetylation, expressed as percentage of activity against kanamycin A substrate as determined by radioassay; $\mathbf{B}$, phosphorylation, expressed as percentage of activity against lividomycin A substrate as determined by radioassay; C, MIC values $\left(\mu \mathrm{g} \mathrm{ml}^{-1}\right)$. The control values for acetylation of kanamycin A were: $P$. aeruginosa 141, 5800 c.p.m.; E. coli SK1592(pBP30), 2201 c.p.m.; E. coli Sk1592(pBP301), 1386 c.p.m.; $P$. aeruginosa 2029(pBP305), 3482 c.p.m. The control values for phosphorylation of lividomycin A were: $P$. aeruginosa 141, 3582 c.p.m.; $E$. coli SK1592(pBP30), 3188 c.p.m.; E. coli SK1592(pBP301), 3092 c.p.m.; P. aeruginosa 2029(pBP305), 3704 c.p.m.
\end{abstract}

\begin{tabular}{|c|c|c|c|c|c|c|c|c|c|c|c|c|}
\hline & \multicolumn{3}{|c|}{$\begin{array}{c}P . \text { aeruginosa } \\
141 \\
(\mathrm{pBP} 30)\end{array}$} & \multicolumn{3}{|c|}{$\begin{array}{r}E . \text { coli } \\
\text { SK } 1592 \\
\text { (pBP30) }\end{array}$} & \multicolumn{3}{|c|}{$\begin{array}{c}\text { E. coli } \\
\text { SK 1592 } \\
\text { (pBP301) }\end{array}$} & \multicolumn{3}{|c|}{$\begin{array}{c}P \text {. aeruginosa } \\
2029 \\
\text { (pBP305) }\end{array}$} \\
\hline & A & B & $\mathrm{C}$ & A & B & $\mathrm{C}$ & A & B & $\mathrm{C}$ & $\mathrm{A}$ & B & $\mathrm{C}$ \\
\hline Kanamycin $\mathbf{A}$ & 100 & 35 & $256^{*}$ & 100 & 32 & $256^{*}$ & 100 & 30 & $256^{*}$ & 100 & 32 & $256^{*}$ \\
\hline Tobramycin & 69 & - & 64 & 88 & -- & 8 & 79 & - & 4 & 80 & - & 16 \\
\hline Sisomicin & 95 & - & 128 & 53 & - & 2 & 59 & - & 2 & 61 & 一 & 2 \\
\hline Dibekacin & 93 & - & 128 & 78 & - & 4 & 66 & — & 4 & 72 & - & 8 \\
\hline Gentamicin $\mathrm{C}_{1 \alpha}$ & 70 & - & 32 & 58 & 一 & 1 & 60 & - & 1 & 56 & - & 2 \\
\hline Neomycin & 49 & 69 & $128^{*}$ & 23 & 62 & $128^{*}$ & 21 & 57 & $64^{*}$ & 25 & 58 & $128^{*}$ \\
\hline Lividomycin A & - & 100 & 1000 & - & 100 & 1000 & $\ldots$ & 100 & 1000 & - & 100 & 1000 \\
\hline Paromomycin & - & 82 & 1000 & - & 84 & 1000 & - & 85 & 1000 & - & 81 & 1000 \\
\hline
\end{tabular}

Table 3. Restriction fragments of pBP301, pBP302, pBP303, and pBP304

Plasmid DNAs were digested with restriction enzymes and the resulting DNA fragments were separated by electrophoresis in 0.8 or $1.2 \%(\mathrm{w} / \mathrm{v})$ agarose slab gels $(25 \times 14 \times 0.4 \mathrm{~cm})$ for $15 \mathrm{~h} \mathrm{at} 3 \mathrm{~V} \mathrm{~cm}^{-1}$. $\lambda$ DNA treated with either EcoRI, HindIII, or PstI was used to provide size markers for digested plasmid DNA.

\begin{tabular}{|c|c|c|c|c|c|c|c|c|c|c|c|}
\hline \multirow[b]{2}{*}{ Fragment } & \multicolumn{11}{|c|}{ Size $(k b)$} \\
\hline & EcoRI & SmaI & XhoI & SalI & $H$ ind II & HindIII & Pst $\mathrm{I}$ & $B g / I$ & $\begin{array}{c}\text { XhoI }+ \\
\text { SmaI }\end{array}$ & $\begin{array}{l}\text { Xhol + } \\
\text { HindIII }\end{array}$ & $\begin{array}{l}\text { SmaI + } \\
\text { HindIII }\end{array}$ \\
\hline A & $11 \cdot 55$ & $11 \cdot 55$ & $9 \cdot 75$ & $5 \cdot 61$ & 5.61 & $8 \cdot 1$ & 4.85 & $2 \cdot 4$ & 9.65 & 6.05 & $7 \cdot 9$ \\
\hline B & & & 1.85 & $5 \cdot 15$ & $3 \cdot 2$ & $2 \cdot 45$ & $2 \cdot 7$ & $2 \cdot 0$ & 1.85 & 2.45 & 2.45 \\
\hline $\mathrm{C}$ & & & & 0.81 & 1.93 & 0.85 & $2 \cdot 45$ & $1 \cdot 6$ & 0.26 & 1.85 & 0.85 \\
\hline D & & & & & $0 \cdot 81$ & & 1.65 & $1 \cdot 2$ & & $0 \cdot 85$ & $0 \cdot 22$ \\
\hline$E$ & & & & & & & & 0.9 & & 0.49 & \\
\hline $\mathrm{F}$ & & & & & & & & 0.7 & & & \\
\hline $\mathrm{G}$ & & & & & & & & 0.57 & & & \\
\hline $\mathrm{H}$ & & & & & & & & $0 \cdot 34^{*}$ & & & \\
\hline I & & & & & & & & $0 \cdot 3$ & & & \\
\hline $\mathrm{J}$ & & & & & & & & $0.23^{*}$ & & & \\
\hline
\end{tabular}

* The corresponding bands in the restriction pattern contain two fragments of the same size.

hybridization (Southern, 1975). DNA of one of the chimaeric plasmids, pBP301, was digested with HindIII and PstI, and $\mathrm{P} 1 \mathrm{Cm}_{\mathrm{ts}}$ DNA with PstI. The fragments were then separated by gel electrophoresis. After transfer from the gel to a nitrocellulose filter they were subjected to Southern hybridization with ${ }^{32} \mathrm{P}$-labelled $\mathrm{P} 1 \mathrm{Cm}_{\mathrm{ts}}$ DNA. Pst $\mathrm{I}$ fragments of phage DNA served as control and could be visualized after a few hours of autoradiography. Even after a three week exposure of the autoradiogram, no sequence homology between Tn2401 and phage DNA was detected. Thus, chromosomal aberrations, as have been described for cointegrates between P1 and the r-determinant of NR1 (Iida \& Arber, 1980), did not seem to direct transposition of $\operatorname{Tn} 2401$.

To confirm the transposition ability of $\operatorname{Tn} 2401$ in the absence of a functional $\operatorname{rec} A$ gene, the 
element was transposed to plasmid R64-11 (Meynell \& Datta, 1976) which codes for resistance to streptomycin and tetracycline. R64-11 was transferred to E. coli K12 recA (pBR322:: Tn2401) by conjugation and then to $E$. coli WA921 with selection for kanamycin resistance. All transconjugants were sensitive to ampicillin but resistant to kanamycin, indicating that pBR322::Tn2401 had not been mobilized while the element Tn2401 had been transposed to R64-11 prior to conjugational transfer. All the exconjugants had lost resistance to either streptomycin or tetracycline. Three tetracycline-sensitive clones and two streptomycin-sensitive clones were further analysed. The MIC values for kanamycin $\left(256 \mu \mathrm{g} \mathrm{ml}^{-1}\right)$, neomycin $\left(64 \mu \mathrm{g} \mathrm{ml}^{-1}\right)$, paromomycin $\left(1 \mu \mathrm{g} \mathrm{ml}^{-1}\right)$, tobramycin $\left(4 \mu \mathrm{g} \mathrm{ml}^{-1}\right)$, dibekacin $\left(4 \mu \mathrm{g} \mathrm{ml}^{-1}\right)$, and tetracycline $\left(256 \mu \mathrm{g} \mathrm{ml}^{-1}\right)$ or streptomycin $\left(256 \mu \mathrm{g} \mathrm{ml}^{-1}\right)$ agreed with the corresponding values for $\mathrm{K} 12$ rec $A$ (R64-11) (pBR322::Tn2401). Analysis of the plasmid DNA from these strains by gel electrophoresis and electron microscopy demonstrated that there were no replicons of the same size as pBP301. Plasmid R64-11 containing Tn2401 was transferred by conjugation with the same frequency as found for R64-11 $\left(10^{-1}\right)$. We concluded that Tn2401 transposed to different sites in R64-11.

\section{Sequence homology with Tn903}

As reported by Oka et al. (1981) Tn903 codes for a phosphotransferase, APH-(3')I. The resistance gene of the element is flanked by large inverted repeats (IS903) $1057 \mathrm{bp}$ in length. Both the structural gene and the insertion element carry characteristic restriction sites: IS 903 is cleaved twice with $S m a I$, and the APH-(3')I gene (aphA) once with XhoI, SmaI, and HindIII. When cleaved with combinations of the three restriction enzymes, pBP301 yielded the same fragments found in the structural gene of $\mathrm{Tn} 903$ in $\mathrm{pSC} 105$, but lacked the fragments produced by cleavage of IS903. Sequence analysis of Tn903 (Oka et al., 1981) demonstrated a length of $276 \mathrm{bp}$ for the $X h o \mathrm{I}-\mathrm{SmaI}$ fragment found in $a p h A, 520 \mathrm{bp}$ for the $X$ hoI-HindIII fragment, and $244 \mathrm{bp}$ for the SmaI-HindIII fragment which resembled the corresponding fragments of Tn2401; the latter were calculated to be $260 \mathrm{bp}, 490 \mathrm{bp}$ and $220 \mathrm{bp}$, respectively (Table 3). Figure 1 shows a heteroduplex structure formed between pSC105, which contains Tn903, and pBP301. An $840 \pm 35$ nucleotide-long region of DNA homology was found in the loop segments of both transposable elements. This homology is in good agreement with the length of aphA (813 nucleotides) reported from the sequence analysis of Tn903 (Oka et al., 1981).

\section{Genetic and physical map of pBP301}

To locate the integration site of Tn2401 in pBR322, a heteroduplex between pBR322 and pBP301 was made and analysed by electron microscopy. The single EcoRI site of pBR322 was used as an internal reference point. A total of 21 heteroduplex structures demonstrated a linear double stranded region with the size of pBR322 DNA and a single stranded loop corresponding to a $7 \cdot 19 \pm 0.33 \mathrm{~kb}$ sequence ( $\operatorname{Tn} 2401$ ) which was $0.34 \mathrm{~kb}$ from the EcoRI site. A short double stranded 'stalk' flanked the loop, representing inverted repeats (Fig. 2). Comparative measurements of the inverted repeats flanking Tn2401 and Tn3 (38 nucleotides; Ohtsubo et al., 1978) revealed the same order of magnitude for both duplications. The loop segment in the heteroduplex molecule also exhibited an internal hairpin loop structure. A total of 25 of the internal hairpin loops were measured. The stem region was calculated to be $0.22 \pm 0.02 \mathrm{~kb}$ and the loop region to be $1.82 \pm 0.07 \mathrm{~kb}$ (Fig. 2).

Plasmid pBP301 was digested with seven different restriction endonucleases (Table 3), singly or in appropriate combinations. After electrophoresis the fragment sizes were calculated. In addition to the restriction analysis, HindIII digests of pBR322 (one fragment) and pBP301 (three fragments) were subjected to heteroduplex analysis and the length of the corresponding structures calculated. From these data a cleavage map of pBP301 could be constructed. By comparison with the heteroduplex structures formed between Tn903 and Tn2401 (Fig. 1), the APH- $\left(3^{\prime}\right)$ I gene was located on the circular restriction map of pBP301 (Fig. 3). 


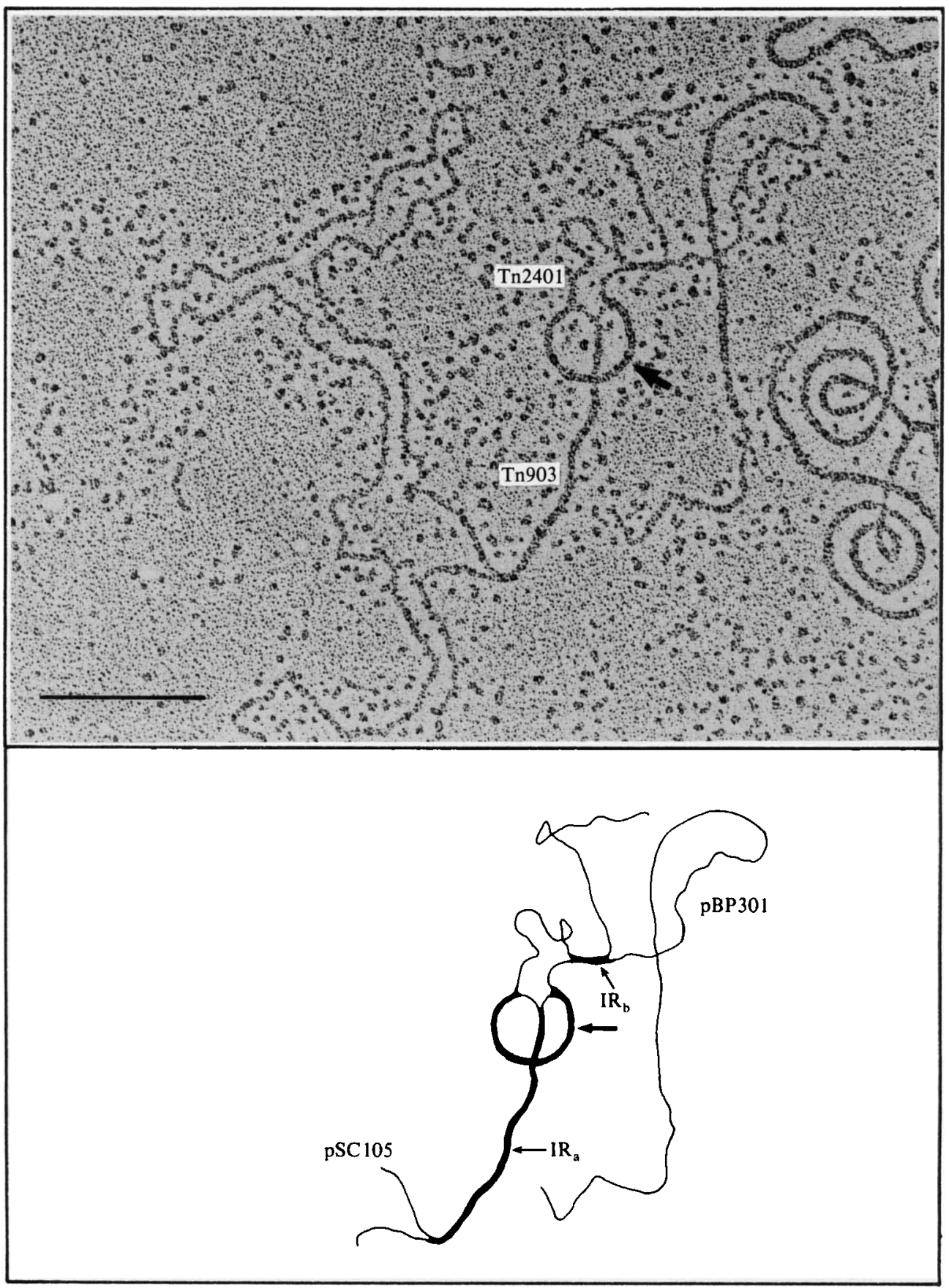

Fig. 1. Heteroduplex formation between $\mathrm{pSC} 105$ and $\mathrm{pBP} 301$. The region of homology formed between the loop structures of $\mathrm{Tn} 2401$ and $\mathrm{Tn} 903$ is indicated by a bold arrow. Inverted repeat (IR) sequences are indicated by fine arrows. IR represents IS903, and $I R_{b}$ represents the $0.22 \mathrm{~kb}$ segment in pBP301. The bar marker represents $0 \cdot 2 \mu \mathrm{m}$. 


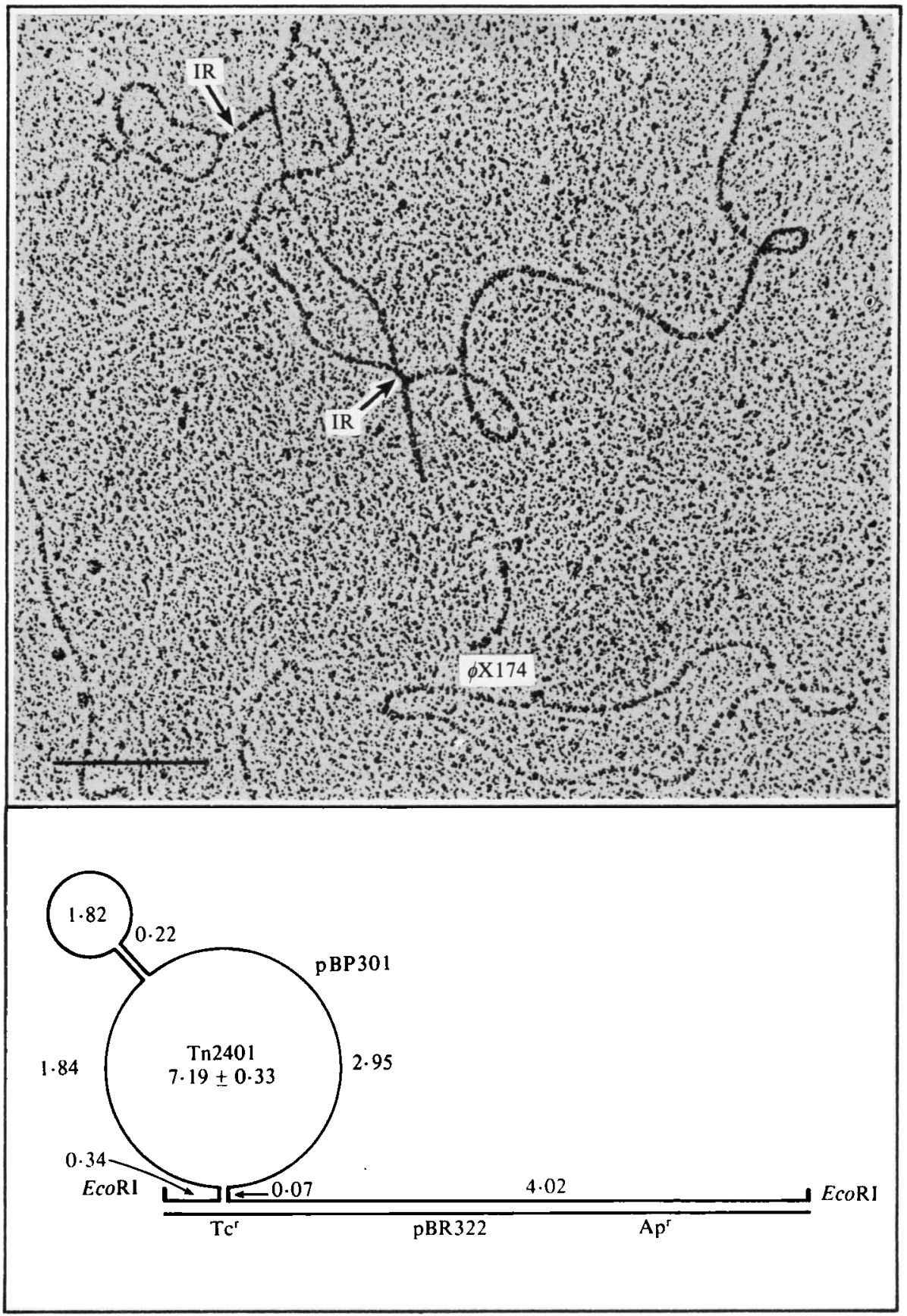

Fig. 2. Heteroduplex formation between pBR322 and pBP301. Both plasmids were digested with EcoRI to give linear molecules prior to denaturation and renaturation of DNA. The position of the two different inverted repeats (IR) are indicated by arrows in the micrograph. Single stranded $\phi$ XI74 DNA is also indicated. The bar marker represents $0 \cdot 2 \mu \mathrm{m}$. 


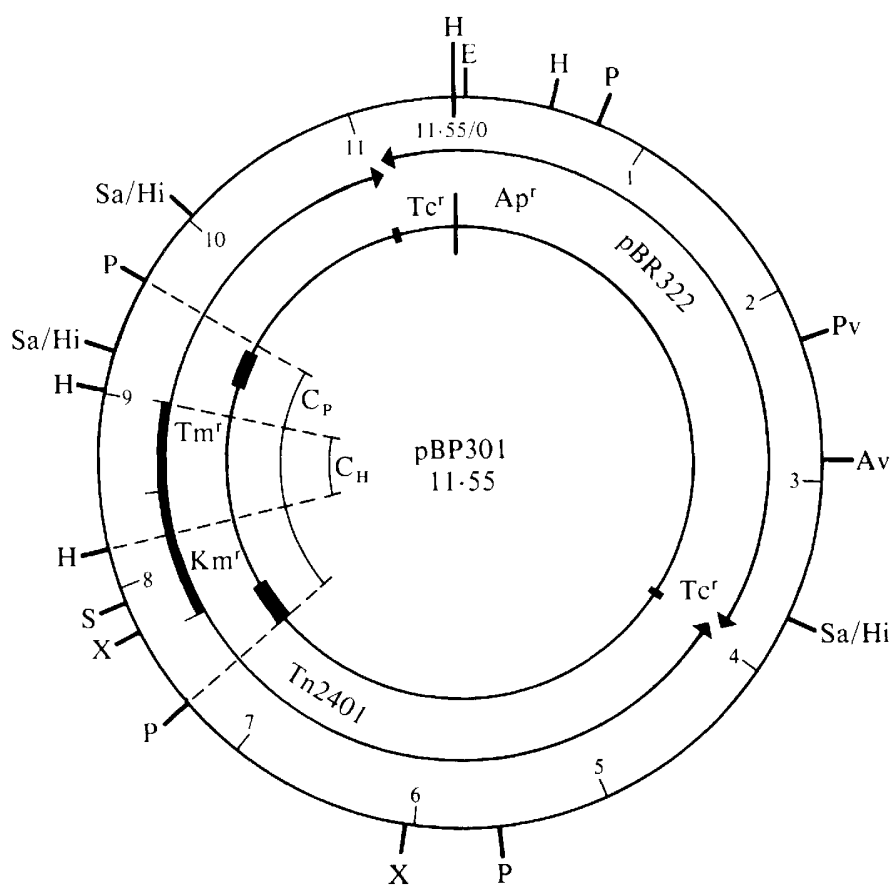

Fig. 3. Circular physical and functional map of pBP301 (pBR322::Tn2401). Coordinates are given in $\mathrm{kb}$ relative to the single HindIII site in pBR322. The small black boxes indicate the position of the inverted repeats. The large box represents the position of $\operatorname{aph} A\left(\mathrm{Km}^{\mathrm{r}}\right)$ and $\operatorname{aac} A\left(\mathrm{Tm}^{\mathrm{r}}\right)$. Restriction fragments used to localize the resistance genes by cloning procedures are designated as follows: $\mathrm{C}_{\mathrm{H}}$, HindIII fragment $\mathrm{C}$; and $\mathrm{C}_{\mathrm{P}}$, Pst I fragment $\mathrm{C}$ (Table 3). Restriction sites: H, HindIII ; E, Eco RI; P, Pst ; Pv, PvuII; Hi, HindII; Sa, SalI; S, SmaI; X, XhoI ; Av, AvaI. The extent of pBR322 and Tn2401 is demonstrated by arrows. The physical data of pBR322 are from Sutcliffe (1978).

\section{Cloning and localization of the $A A C-\left(6^{\prime}\right)$ gene}

Pst I-generated fragments of pBP301 were cloned into the wide host range plasmid RSF 1010. Pst I cleaved RSF1010 twice, yielding a small fragment covering the functions for replication and the streptomycin resistance gene. Ligated fragments were transformed into $E$. coli SK 1592 and the resulting clones selected on tobramycin and paromomycin, the antibiotics inactivated by AAC- $\left(6^{\prime}\right)$ and APH- $\left(3^{\prime}\right) \mathrm{I}$, respectively. All the clones that were resistant to tobramycin, paromomycin and streptomycin but sensitive to sulphonamides contained Pst I fragment C integrated into RSF1010 (see Fig. 3). This result was confirmed and further defined by deletion of HindIII fragments from pBP301 and subsequent transformation of the resulting plasmids. Analysis of the corresponding clones revealed that the deletion of the smallest HindIII fragment, $\mathrm{C}$, resulted in complete sensitivity to all aminoglycosides, while antibiotic susceptibility was not influenced by loss of fragment $\mathrm{B}$. On the basis of these data aac $A$ could be localized next to the aphA (Fig. 3).

\section{Restriction map of the aminoglycoside resistance region of Tn240I}

To construct a fine structural map of the resistance determinant segment of Tn2401, suitable restriction fragments from pBP301 were separated by electrophoresis on Sea-plaque agarose (FMC, Rockland, Me 04841, U.S.A.), isolated, purified and subjected to further restriction analysis on polyacrylamide gels. HindIII fragment $\mathrm{C}$, which is known to contain part of aphA and $a a c C$, and $P s t I$ fragment $C$, containing both resistance genes, were purified and digested with restriction enzymes $S a u 3 \mathrm{~A}, B g I \mathrm{I}, B g l \mathrm{II}, H p a \mathrm{II}, S a / \mathrm{I}$, or $A l u \mathrm{I}$. The relative locations of the cleavage sites were determined by digestion, using restriction sites on Tn903 (Oka et al., 1981) as 


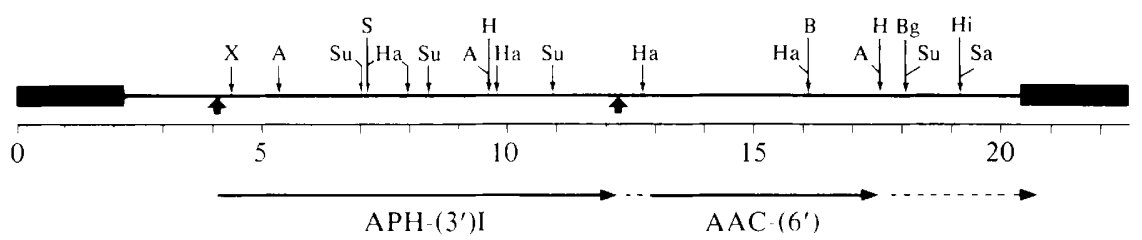

Fig. 4. Physical and functional map of the resistance region of Tn2401. Black boxes indicate inverted repeats. Coordinates are given in $100 \mathrm{bp}$ units. The extent of homology to Tn903 is within the bold arrows. The coding regions of $\mathrm{APH}-\left(3^{\prime}\right) \mathrm{I}$ and $\mathrm{AAC}-\left(6^{\prime}\right)$ are represented by continuous lines; broken lines represent the possible extent of the AAC- $\left(6^{\prime}\right)$ coding region (see text). The APH- $\left(3^{\prime}\right) \mathrm{I}$ map is from Oka et al. (1981). Restriction sites: X, XhoI; H, HindIII;S, SmaI ; B, BglI; Bg, BglII; A, AluI; Sa, SalI ; Hi. HindII; Su, Sau3A; Ha, HpaII. Three HpaII fragments in the BglI-HindII fragment are not indicated, since their order remains unclear.

reference points. The cleavage map derived from these data and the heteroduplex analysis between Tn903 and Tn2401 (Fig. 1) is shown in Fig. 4.

\section{DISCUSSION}

We report the isolation of a new transposable element, Tn2401, coding for the production of two aminoglycoside inactivating transferases, AAC- $\left(6^{\prime}\right)$ and APH- $\left(3^{\prime}\right) \mathrm{I}$. In P. aeruginosa, resistance to gentamicin, tobramycin, sisomicin, netilmycin, and dibekacin is mediated by aac $A$ of Tn2401, while resistance to paromomycin, lividomycin, kanamycin, and neomycin is due to the phosphotransferase, APH- $\left(3^{\prime}\right) \mathrm{I}$. As shown by heteroduplex mapping and restriction analysis, the APH-( $\left.3^{\prime}\right) \mathrm{I}$ genes of Tn2401 and Tn903 are homologous. As no additional homologous sequences were detected, the remaining parts of the transposons appear to have originated from different sources.

As deduced from the cloning experiments, the length of aac $A$ is between 0.6 and $0.8 \mathrm{~kb}$. The exact length of the gene remains unclear, since neither the control region nor the terminating codon is known. The $0.22 \mathrm{~kb}$ inverted repeats on either side of the resistance genes in Tn2401 are interesting, but their function is not yet understood.

Four independent clones harbouring pBR322::Tn2401 were isolated. A comparison of their restriction patterns indicates that the transposable element might have inserted into a specific site in pBR322. Additional experimental data are required to determine if the integration of Tn2401 is site-specific, a phenomenon which has been reported for only a few transposable elements, such as Tn554 (Krolewski et al., 1981) and Tn7 (Lichtenstein \& Brenner, 1982). Tn7 transposes to other sites when the attachment site is not available, a process which might be compared with the integration of Tn2401 in R64-11. Until these integration sites on R64-11 have been mapped or sequenced, it cannot be deduced whether multiple sites or only two preferred sites are available in R64-11 for integration of $\mathrm{Tn} 2401$ - one in the $\mathrm{Sm}^{\mathrm{r}}$ gene and one in the $\mathrm{Tc}^{\mathrm{r}}$ gene. The latter may be the same as the integration sites in pBR322.

Exact physical data about the characteristics of the target sequence and mutants defective in transposition will help to understand the nature of $\mathrm{Tn} 2401$ and the way genes encoding AAC$\left(6^{\prime}\right)$ disseminate in Gram-negative hosts.

We thank R. G. McKenzie for critical reading of the manuscript and A. K. Rottenbacher for excellent technical assistance. This work has been supported by a grant of the Deutsche Forschungsgemeinschaft to F.S.

\section{REFERENCES}

ACar, J. F., Bouanchaud, D. H. \& Chabbert, Y. A. (1977). Evolutionary aspects of plasmid mediated resistance in a hospital environment. In Topics in Infectious Diseases, vol. 2. R-factors: Their Properties and Possible Control, pp. 5-23. Edited by J. Drews \& G. Högenauer. New York: Springer Verlag.
Bachmann, B. J. (1972) Pedigrees of some mutant strains of Escherichia coli. Bacteriological Reviews 36, 525-527.

Beneviste, R. \& Davies, J. (1971). Enzymatic acetylation of aminoglycoside antibiotics by Escherichia coli carrying an R-factor. Biochemistry 10, 1787-1796. 
Beneviste, R. \& Davies, J. (1973). Mechanism of antibiotic resistance in bacteria. Annual Review of Biochemistry 42, 471-506.

Bolivar, F., Rodriguez, R. L., Greene, P. J., Betlach, M. C., Heynecker, H. L. \& Boyer, H. W. (1977). Construction and characterization of new cloning vehicles. II. A multipurpose cloning system. Gene 2, 95-113.

Botchan, M., Topp, W. \& Sambrook, J. (1976). The arrangement of Simian Virus 40 sequences in the DNA of transformed cells. Cell 9, 269-274.

Cohen, S. N., Chang, A. C. \& Hsu, L. (1972). Nonchromosomal antibiotic resistance in bacteria: genetic transformation of Escherichia coli by R-factor DNA. Proceedings of the National Academy of Sciences of the United States of America 69, 2110 2114.

Davis, R. W., Simon, M. \& Davidson, N. (1971). Electron microscope heteroduplex methods for mapping regions of base sequence homology in nucleic acids. Methods in Enzymology 21, 413-428.

Guerry, P., van Embden, J. D. A. \& Falkow, S. (1974). Molecular nature of two nonconjugative plasmids carrying drug resistance genes. Journal of Bacteriology 117, 619-630.

IIDA, S. \& ARBER, W. (1977). Plaque forming specialized transducing phage P1: isolation of $\mathrm{P} 1 \mathrm{Cm} \mathrm{Sm} \mathrm{Su}$, a precursor of $\mathrm{P} 1 \mathrm{Cm}$. Molecular and General Genetics 153, 259-269.

IIDA, S. \& ARBER, W. (1980). On the role of ISI in the formation of hybrids between the bacteriophage P1 and the R plasmid NR1. Molecular and General Genetics 177, 261-266.

Krolewski, J. J., Murphy, E., Novick, R. P. \& Rush, M. G. (1981). Site-specificity of the chromosomal insertion of Staphylococcus aureus transposon Tn554. Journal of Molecular Biology 152, 19-33.

K USHNER, S. R. (1978). An improved method for transformation of Escherichia coli with ColEl derived plasmids. In Proceedings of the International Symposium of Genetic Engineering, pp. 17-23. Edited by $\mathbf{H}$. W. Boyer \& S. Nicosia. Amsterdam: Elsevier/North Holland.

LEDERBERG, E. (1981). Plasmid reference center registry of transposon ( $\mathrm{Tn}$ ) allocations through July 1981. Gene 16, 59-61.

LiCHTENSTEIN, C. \& BRENNER, S. (1982). Unique insertion site of $\operatorname{Tn} 7$ in the $E$. coli chromosome. Nature, London 297, 601-603.

Maniatis, T., Jeffrey, A. \& Kleid, D. G. (1975). Nucleotide sequence of the rightward operator of phage $\lambda$. Proceedings of the National Academy of Sciences of the United States of America 72, 1184 1187.

Meynell, F. \& DatTA, N. (1976). Mutant drug resistance factors of high transmissibility. Nature, London 214, 885-887.

MISE, K. \& ARBER, W. (1976). Plaque-forming transducing bacteriophage $\mathrm{Pl}$ derivatives and their behaviour in lysogenic conditions. Virology 69, 191205.

Nisen, P. D., Kopecko, D. J., Chow, J. \& Cohen, S. (1977). Site specific DNA deletions occurring adjacent to the termini of a transposable ampicillin element (Tn3). Journal of Molecular Biology 117, 975-998
Nugent, M. E., Bone, D. H. \& Datta, N. (1979). A transposon, $\operatorname{Tn} 732$, encoding gentamicin/tobramycin resistance. Nature, London 282, 422-423.

Ohtsubo, H., OHMORI, H. \& OHTSUBo, E. (1978). Nucleotide sequence analysis of Tn3 (Ap): implications for insertion and deletions. Cold Spring Harbor Symposia on Quantitative Biology 43, 12691277.

Oka, A., Sugisaki, H. \& Takanami, M. (1981). Nucleotide sequence of the kanamycin resistance transposon Tn903. Journal of Molecular Biology 117, 975-998.

RoSNER, J. L. (1972). Formation, induction, and curing of bacteriophage Pl lysogens. Virology 49, 679689.

Sanger, F., Air, G. M., Barell, B. C., Brown, N. L., Coulson, A. R., Fiddes, J. C., Hutschinson, C. A. III, Slocombe, P. M. \& SMith, M. (1977). Nucleotide sequence of bacteriophage $\phi \times 174$ DNA. Nature, London 265, 687-695.

SchmidT, F., van Treeck, U. \& Wiedemann, B. (1982). Multimerization and replication of plasmid pBP11. Plasmid 8, 126-140.

Sinclair, M. J. \& Morgan, A. F. (1978). Transformation of Pseudomonas aeruginosa strain PAO with bacteriophage and plasmid DNA. Australian Journal of Biological Sciences 31, 679-685.

Southern, E. M. (1975). Detection of specific sequences among DNA fragments separated by gel electrophoresis. Journal of Molecular Biology $\mathbf{9 8}$, 503-517.

Starlinger, P. (1980). IS elements and transposons. Plasmid 3, 241-259.

SutClifFe, J. G. (1978). Complete nucleotide sequence of the Escherichia coli plasmid pBR322. Cold Spring Harbor Symposia on Quantitative Biology 43, 7790

van Treeck, U., Schmidt, F. \& Wiedemann, B. (1981). Molecular nature of a streptomycin and sulfonamide resistance plasmid ( $\mathrm{pBP} 1$ ) prevalent in clinical Escherichia coli strains and integration of an ampicillin transposon (TnA). Antimicrobial Agents and Chemotherapy 19, 371-380.

WAHL, G. M., Stern, M. \& Stark, G. R. (1979). Efficient transfer of large DNA fragments from agarose gels to diazobenzyloxymethyl-paper and rapid hybridisation by using dextran sulfate. Proceedings of the National Academy of Sciences of the United States of America 76, 3683-3687.

Wiedemann, B. \& Weppelmann, G. (1981). Aminoglykosidantibiotika-modifizierende Enzyme. Infection and Immunity 9, 106-112.

WoOD, W. B. (1966). Host specificity of DNA produced by Escherichia coli: bacterial mutations affecting the restriction and modification of DNA. Journal of Molecular Biology 169, 118-133.

Yamamoto, T. \& Yokota, T. (1980). Construction of a physical map of a kanamycin $(\mathrm{K} \mathrm{m})$ transposon, $T \mathrm{n} 5$, and comparison to another $\mathrm{Km}$ transposon, $\mathrm{Tn} 903$. Molecular and General Genetics 178, 77-83.

Yoshikawa, T. T., Shibata, S. A., Chow, B. W. \& Guze, L. B. (1978). Outbreak of multiple drugresistant Proteus mirabilis originating in a surgical intensive care unit: in vitro susceptibility pattern. Antimicrobial Agents and Chemotherapy 13, 177181. 